\title{
THREE EDITIONS OF «THE FUNDAMENTAL VALUES OF ACADEMIC INTEGRITY» AS A RESOURCE FOR EDUCATORS
}

\author{
ТРИ ВИДАННЯ ТНЕ FUNDAMENTAL VALUES \\ OF ACADEMIC INTEGRITY ЯК OCВITHIЙ PECУPC
}

The paper shows the results of study aimed at assessment of the editions of «The Fundamental Values of Academic Integrity» from the point of view of its usage in the educational process. They contain information on the academic integrity values with the detailed description of the notions and comments on the most important ideas, academic integrity support.

The research methodology is substantiated by the aim of the paper defined as to describe the peculiarities of three editions of «The Fundamental Values of Academic Integrity» from the point of view of possibility of its active engagement into the educational process of different students of various fields of study. The line of works describes the changes of the system of academic integrity values, as well the understanding of their role in academic integrity support. The functions of separate stakeholders of educational process are also shown in their dynamics and transformation from the concept of perception to the concept of activity and active participation as an important indicator of values sharing. The three editions of «The Fundamenta Values of Academic Integrity» being first of all the general source of information for raising awareness in the sphere of academic integrity is also an important resource book for creation of various educational activities for students of different educational levels. The books are easy to use in educational context with the purpose to develop the activity component of the idea of academic integrity of students and educators. The ways of using the three editions of «The Fundamental Values of Academic Integrity» in the educational process are quite diverse and depend on the educational purposes. They provide the most important general provisions being easy to transform and adapt to the requirements of particular situations and conditions of an educational institution.

Key words: academic integrity values, honesty, trust, fairness, respect, responsibility, courage.

y статті наведено результати дослідження, спрямованого на оцінку видань «Фундаментальних иінностей академічної доброчесності» 3 погляду їх використання у навчальному прочесі. Вони містять інсрормацію про цінності академічної доброчесності з докладним описом ключових понять та коментарями щодо найважливіших іеей, підтримки академічної доброчесності, а також цитати науковців, срілософрів, видатних особистостей. Методологія дослідження обірунтована метою статmі, яка визначається як опис особливостей трьох видань «Фундаментальних цінностей академічної доброчесності» з погляду можливості його активного залучення до навчального процесу різних студентів різних галузей навчання. Низка робіт описує зміни в системі чінностей академічної доброчесності, а також розуміння їхньої ролі в підтримці академічної доброчесності. Функції окремих стейкхолдерів освітнього процесу також виявляються в їх динаміці та перетворенні від концепції сприйняття до концепції діяльності та активної участі як важливого показника обміну цінностями. Три видання «Фундаментальних иінностей академічної доброчесності», які є в першу чергу загальним джерелом інфрормації для підвищення обізнаності в галузі академічної доброчесності, також $є$ важливим посібником для створення різноманітних навчальних ресурсів для студентів різних освітніх рівнів. Книги прості у використанні в освітньому контексті з метою розвитку активного компоненту ідеї академічної доброчесності студентів та викладачів. Способи використання трьох видань «Фундаментальних цінностей академічної доброчесності» у навчальному процесі досить різноманітні та залежать від освіт ніх цілей. Вони забезпечують найважливіші загальні положення, які легко транссрормувати та адаптувати до вимог конкретних ситуацій та умов навчального закладу, що можна назвати їх значною перевагою порівняно з іншими ресурсами.

Ключові слова: чінності академічної доброчесності, чесність, довіра, справедливість, повага, відповідальність, мужність.

There were three editions of the paper The

Problem statement in general and its connection with important scientific or practical tasks. Academic integrity is one of the most highly discussed issues among the educators, particularly due to the need of quality of education assurance in cases of online and blended learning. It is considered from different points of view resulting from the complex nature of this phenomenon. But such varying approaches are based on the same fundamentals being referred as core values or fundamental values of academic integrity. The list of the values was prepared by the researchers from the USA International Center for Academic Integrity (ICAI) as a result of their research and practical activity concerning the issue of academic integrity.
Fundamental Values of Academic Integrity (1999, 2014, and 2021). They contain information on the academic integrity values with the detailed description of the notions and comments on the most important ideas, academic integrity support. As the authors state, «by articulating the fundamental values of academic integrity, ICAI attempts to frame academic integrity in ways that are both positive and pragmatic» [8].

Analysis of recent research and publications. The issue of academic integrity is of great interest for modern researchers in the world, particularly resulting from the need of maintaining academic integrity in the conditions of blended and online learning created by the pandemic situation [5;9]. The values of academic 
integrity are considered as the fundamental of fundamentals, and researches tend to refer to them in different contexts. But the core values of academic integrity are often mentioned in the scientific literature as source of information on the topic [3] and when providing the definitions of some basic ideas [2]. The researchers develop the concept of the values described and provide their reflections or ways of further studies in the field. It is worth mentioning that a range of studies represent the values of academic integrity in the view of investigation of the system of general values of students and society in general [4].

There are also some projects developed by educationalists from different regions that refer to the values of academic integrity and present them in the form being suitable for using in the classroom activities [1].

Highlighting of previously unsolved parts of the general problem. But the educational prospective of using different editions of publication in the educational process mostly remain uncovered. The only way of using the books is considering them as a reference book for definitions and basic ideas concerning the theme of academic integrity. Although the website of ICAI provides the English text of the book and translations into some other languages, they remain the collection of the basic definitions.

The purpose of the paper is to describe the peculiarities of three editions of «The Fundamental Values of Academic Integrity» from the point of view of possibility of its active engagement into the educational process of different students of various fields of study.

Research methods. The reliability of the research results is based on the application of the method of content analysis used to distinguish the main peculiarities of the editions of «The Fundamental Values of Academic Integrity» resulting in their efficient use in the educational process.

Presentation of the main material. Although the idea of academic integrity has become urgent many years ago, a lot of problems associated with this idea still remain, and a lot of students and even researchers face the problems of academic integrity support. The problems are solved in different ways. In the United States of America there are many resources for students and professors concerning the issues of academic integrity and ways of learning and doing their research in a proper way. One of the most fundamental results of US researchers work is the book «The Fundamental Values of Academic Integrity», which has three editions by now. This fundamental paper helps us understand and their value rationale, the values being the basic for academic integrity and academic integrity support among students in high school and colleges and universities.

The 1st edition of this research results appeared in 1999 , and it has shown the idea of academic integrity in line with such values of academic integrity as honesty, trust, fairness, respect, and responsibility. The values became the basis of behaviour peculiarities needed to transform the ideas into the action.

The book also presents the definition of the notions, ideas, and values associated with academic integrity. The inevitable part of edition is the quotations of different persons uncovering the values of academic integrity and their applications in various situations, in particular academic practice. The quotations may be used as a suitable source of educational activities, discussions, and reflections. The origin of the quotation is different; they represent the ideas of students of leading universities and the researchers from the United States about values and their role in academic integrity support. This resource is of great value for educators from different points of view. First of all, this is a source of background material providing important information about the idea of academic integrity and its connection to the values as a general notion and values of academic integrity in particular.

The content of the book encourages the reflection on the material provided, so it can be used by students as part of their independent study and independent research. And also it can be used for different discussions, inclass discussions, and seminars. The quotations are important from this point of view, so all of them can be used by students and by the educators when organising different events associated with academic integrity and encouraging students' discussions and debates on this idea.

This first edition of «The Fundamental Values of Academic Integrity» contains the recommendations not only for educators delivering lessons, but also resources for educational institutions policy makers. According to the authors of the book, the successful practice of academic integrity supposes that an academic institution should:

1. Have clear academic integrity statements, policies, and procedures that are consistently implemented.

2. Inform and educate the entire community regarding academic integrity policies and procedures.

3. Promulgate and rigorously practice these policies and procedures from the top down, and provide support to those who faithfully follow and uphold them.

4. Have a clear, accessible, and equitable system to adjudicate suspected violations of policy.

5. Develop programs to promote academic integrity among all segments of the campus community. These programs should go beyond repudiation of academic dishonesty and include discussions about the importance of academic integrity and its connection to broader ethical issues and concerns.

6. Be alert to trends in higher education and technology affecting academic integrity on its campus. 
7. Regularly assess the effectiveness of its policies and procedures and take steps to improve and rejuvenate them [6, p. 10].

This general frame forms the base for the development of policies of different educational institutions in the sphere of academic integrity promotion and quality of education assurance.

So, the first edition of «The Fundamental Values of Academic Integrity» is a kind of reference book for various educational practitioners and institutional policy-makers.

The second edition of this work was compiled in 2014. This is second edition was also provided by the International Center of Academic integrity and edited by Tony Fishman. The mainstream of this work is set by the quotations presenting the ideas of famous people concerning the general values. These are the values which are connected with academic integrity, so these are the same values as the values integrity, but they are viewed from their philosophical nature. The points of view of Frederick Douglass, Eleanor Roosevelt, Confucius and other outstanding persons begin this edition and they let the reader plunge into the idea of academic integrity. So this addition is prepared to provide us with deeper plunge into the problem of academic integrity not only presenting the values, but also describing the general idea of academic integrity. And then we have the fundamental values considered in a broader context and sixth value added and introduced. This value is courage, which is determined as the ability to support, to promote, to maintain the system of basic values mentioned in the previous edition.

The invitation to the work shows a brief history of academic integrity concept and indicates the lists of organizations supporting the firs and these second editions. The role of academic integrity is also highlighted. The idea of Youngsup Kim, ICAI Conference Participant states that «Academic integrity is a way to change the world. Change the university first; then change the world» [7, p. 15].

The chapter devoted to each value contains the definition of the value, a range of quotations associated with its meaning and role, the examples of behaviour demonstrating the proper value and behaviour demonstrating the negligence of the value. Let's consider the chapter for honesty. It starts from the quotations by different outstanding people showing the importance of honesty. And also we have the definition of honesty, the definition of honest behaviour and dishonest behaviour. The chapter also provides students and readers with understanding of this concept.

The chapter for trust has the same structure for trust; moreover, it contains the justification of the necessity of trust. Then the ideas of fairness, respect, and responsibility are introduced in the same way. And the last chapter is devoted to courage. It is highlighted that «translating the values from talking points into action - standing up for them in the face of pressure and adversity - requires determination, commitment, and courage» [7, p. 26].

The main peculiarity of this second edition of «The Fundamental Values of Academic Integrity» is the special attention to the importance of actions in the process of academic integrity maintaining. The authors specify that the understanding and knowledge is not enough for academic integrity support, the real actions are required as well as the proper behaviour. This idea has also become the basis for the transformation of the chapter «Developing Effective Academic Integrity Programs». The previous edition contained such a chapter, but in this edition the concept is introduced from the paradigm of activities and concrete steps «that can be taken to maximize chances for success» [7, p. 28].

The third edition of was introduced in 2021 «The Fundamental Values of Academic Integrity». The structure of the work is similar, but the definitions of the main notions are provided on the base of MerriamWebster dictionary. The chapters were also enriched with the passage «Ways to demonstrate...». For example, the following ways to demonstrate respect are considered:

- Practice active listening;

- Receive feedback willingly;

- Accept that others' thoughts and ideas have validity:

- Show empathy;

- Seek open communication;

- Affirm others and accept differences;

- Recognize the consequences of our words and actions on others [8, p. 8].

This edition describes the situations meaning that the stakeholders of educational process (students, faculty, and members of academic communities) show the proper value.

The last chapter entitled «How to Create a Culture of Academic Integrity» contains a range of recommendations for systematic policy of academic integrity support. It is highlighted that academic integrity programmes may vary in different organizations, but «the relationship between policies and procedures, community standards, and day-today conduct should be congruent, consisted, and compatible with the institutional mission, vision, and values» [8, p. 14]. The edition also contains the list of useful resources associated with academic integrity and its maintenance in educational institutions.

The three editions of the paper «The Fundamental Values of Academic Integrity» show the peculiarities of the development process of the concept of academic integrity and attitudes towards its maintenance. The line of works describes the changes of the system of academic integrity values, as well the understanding of their role in academic integrity support. The functions 
of separate stakeholders of educational process are also shown in their dynamics and transformation from the concept of perception to the concept of activity and active participation as an important indicator of values sharing.

The need to create the efficient environment for academic integrity maintenance is considered in all three editions with various levels of detalization and approach. The authors highlight the main role of academic community and academic environment for the development of academic integrity of students at different levels of education. The points are useful for policy makers from the educational institutions as a background for the development of various statements, policies, codes of conduct for students and pedagogical staff, manuals and so on.

The works are valuable from the educational point of view in various aspects. They can be used as a reader, the source book, and as a manual supporting different types of educational activity. First of all, the editions of «The Fundamental Values of Academic Integrity» are of great importance for the educators and students, who are on their way to understand the nature and peculiarities of the phenomenon of academic integrity and its connection to the system of modern individual's values and beliefs. They contain a lot of materials for discussions and further reflection (definitions and quotations of different persons) as well as encouraging additional reading and reflections on the topic.

Conclusions. The three editions of «The Fundamental Values of Academic Integrity» being first of all the general source of information for raising awareness in the sphere of academic integrity is also an important resource book for creation of various educational activities for students of different educational levels. The books are easy to use in educational context with the purpose to develop the activity component of the idea of academic integrity of students and educators.

The information provided in the volumes is various and may be used as it is or form the base for new educational resources development. Some elements of the editions may become a part of courses syllabi or codes of conduct for students and educators. If there is a specific course devoted to the issues of academic integrity development or maintenance for students, the «The Fundamental Values of Academic Integrity» may provide the material for discussions and reflections.

So, the ways of using the three editions of «The Fundamental Values of Academic Integrity» in the educational process are quite diverse and depend on the educational purposes. They provide the most important general provisions being easy to transform and adapt to the requirements of particular situations and conditions of an educational institution.

\section{REFERENCES:}

1. Chukanova S. Fundamental Values of Academic Integrity. Honesty. URL: http://ekmair.ukma.edu.ua/ bitstream/handle/123456789/14517/AI_FV_Eng. pdf?sequence $=1$

2. Clark A., Goodfellow J. Shoufani S. Examining academic integrity using course-level learning outcomes. The Canadian Journal for the Scholarship of Teaching and Learning. 2020. № 11(2). https://doi.org/10.5206/ cjsotl-rcacea.2020.2.8508

3. Muhammad A., Shaikh A., Naveed Q. N., Qureshi M. R. N. Factors affecting academic integrity in e-learning of Saudi Arabian universities. An investigation using Delphi and AHP. IEEE Access. 2020. Vol. 8. P. 16259-16268 doi: 10.1109/ACCESS.2020.2967499.

4. Ramdani Z. Construction of academic integrity scale. International Journal of Research Studies in Psychology. 2018. Vol. 7, № 1, P. 87-97

5. Sopcak P. Academic Integrity and the Pandemic. Canadian Perspectives on Academic Integrity. 2020. Vol. 3, № 2 https://doi.org/10.11575/cpai.v3i2.71649

6 . The fundamental values of academic integrity. Des Plaines: Oakton Community College, 1999.

7. The fundamental values of academic integrity. 2nd ed./ ed. T. Fishman (Ed.). Clemson: Clemson University, 2014 .https://doi.org/10.15713/ins.mmj.3

8. The fundamental values of academic integrity. 3rd ed. I International Center for Academic Integrity [ICAI]. 2021. URL: www.academicintegrity.org/thefundamental-valuesof-academic-integrity

9. Trynus O. Academic integrity: challenges of modernity. UNESCO Chair Journal "Lifelong Professional Education in the XXI Century". 2020. № 1. P. 69-72. https://doi.org/10.35387/ucj.1(1).2020.69-72 